\title{
Evaluating the Heavy Metal Risks of Soil and Rice from a Farmland in a Nanjing Suburb through In-vitro Simulation Tests
}

\author{
Chenghui Han ${ }^{1 *}$, Weifang Xie ${ }^{1}$, Chen Chen ${ }^{2}$, Ting Cheng ${ }^{1}$ \\ ${ }^{1}$ School of Environment and Ecology, Jiangsu Open University, Nanjing 210036, China \\ ${ }^{2}$ School of Environmental and Chemical Engineering, Jiangsu University of Science and Technology, \\ Zhenjiang 212003, China
}

Received: 7 June 2020

Accepted: 15 September 2020

\begin{abstract}
The risks from heavy metals in soil and rice from a farmland in a Nanjing suburb, southeastern China, were evaluated using the geo-accumulation index, a health risk assessment and an in-vitro simulation. The concentrations of heavy metals $(\mathrm{Pb}, \mathrm{Cr}, \mathrm{Zn}, \mathrm{Cu}, \mathrm{Cd}, \mathrm{Hg}$, and $\mathrm{As})$ in the soil and rice were determined in the present study. The results showed that at the two stages measured, the order of geoaccumulation index values (except those of $\mathrm{Pb}$ and $\mathrm{Zn}$ ) was $\mathrm{Cd}>\mathrm{As}>\mathrm{Hg}>\mathrm{Cu}>\mathrm{Cr}$. Moreover, the heavy metals with lower $\mathrm{I}_{\text {geo }}$ values exhibited lower risks at both stages in the study area. The farmland in the study area was not polluted by heavy metals, according to the evaluation of the total heavy metal contents and their chemical speciation. The order of bio-concentration factor was $\mathrm{Cd}>\mathrm{Cu}>\mathrm{Zn}>\mathrm{Pb}>\mathrm{As}>\mathrm{Cr}>\mathrm{Hg}$. For all heavy metals, the non-carcinogenic doses of the different exposure pathways indicated that $\mathrm{CDI}_{\text {ing-nc }}>\mathrm{CDI}_{\text {dermal }}>\mathrm{CDI}_{\text {inh-nc }}$ for children and adults. The HI values for adults and children from heavy metals before rice sowing were 0.0984 and 0.634 , respectively, indicating that these metals had little influence on the human body. The HI values for adults and children for heavy metals at the rice harvesting stage were 0.146 and 0.879 , respectively. Before rice sowing, the lifetime carcinogenic risk values for local adults and children were $5.60 \times 10^{-5}$ and $8.15 \times 10^{-5}$, respectively. At the rice harvesting stage, the lifetime carcinogenic risk values for local adults and children were $3.01 \times 10^{-5}$ and $4.48 \times 10^{-5}$, respectively. At both stages, the order of $\mathrm{CF}$ values for adults and children was $\mathrm{Cd}>\mathrm{Cr}>\mathrm{As}>\mathrm{Pb}$. The total amounts and bioavailable amounts of the heavy metals ingested by adults and children through eating the local rice did not exceed the tolerable weekly intake values, indicating that there is no health risk from eating the local rice. However, draining and drying the field at the proper time would improve the Eh value of the paddy soil.
\end{abstract}

Keywords: heavy metals, rice, geo-accumulation index, health risk assessment, in-vitro simulation test

*e-mail: hanch69@sina.com 


\section{Introduction}

Heavy metal pollution has been widely studied because it causes environmental and public health problems worldwide [1]. Heavy metals and metalloids ( $\mathrm{Hg}$ and $\mathrm{As}$ ) can be not degraded and these elements are easily enriched in soils. They can enter the human body through the food chain and accumulate continuously [2]. The extensive use of sewage irrigation, pesticides and chemical fertilizers makes the content of heavy metals continuously accumulate and aggravate in farmland [3]. The contamination of agricultural products with heavy metals has become an important factor that restricts the sustainable development of agriculture and rural economies. Therefore, it is urgent to determine the level of heavy metals in farmland and take corresponding measures to solve the series of resulting ecological issues.

Rice is one of the main staple crops in Jiangsu Province. When the cadmium content of rice is excessive, it will affect rice growth, development, yield and quality. In particular, cadmium accumulation poses a serious threat to the life and health of humans and livestock due to biological amplification in the food chain and even affects the quality and safety of rice [4]. In comparison with its tolerance of other heavy metals and metalloids, rice has a stronger tolerance to $\mathrm{Cd}$, however, $\mathrm{Cd}$ easily becomes concentrated in rice [5]. Li et al. [6] conducted field and pot experiments to evaluate the factors affecting heavy metal accumulation in rice grain and subsequently to explore the differences among rice cultivars when exposed to $\mathrm{Cd}$. The results showed that of the tested metals, $\mathrm{Cr}$ and $\mathrm{Cd}$ were the dominant contaminants in samples from the test areas, with $100.0 \%$ and $59.6 \%$ of all grain samples exceeding the maximum permissible concentration. Lei et al. [7] demonstrated the pollution conditions and human health risks by determining the concentrations of the heavy metals $(\mathrm{Pb}, \mathrm{Cd}, \mathrm{Cu}$, and $\mathrm{Zn})$ in paddy soils and white rice around seven mining-affected areas in Hunan Province. The ranges of concentrations of $\mathrm{Pb} \quad(23.9-1595.8 \mathrm{mg} / \mathrm{kg}), \quad \mathrm{Cd} \quad(0.3-9.5 \mathrm{mg} / \mathrm{kg})$, $\mathrm{Cu}$ (31.2-321.5 $\mathrm{mg} / \mathrm{kg})$ and $\mathrm{Zn}(56.1-3478.9 \mathrm{mg} / \mathrm{kg})$ in all paddy soils were significantly higher than the background values for Hunan Province and even exceeded the maximum permissible concentrations for paddy soil quality recommended by the Ministry of Environmental Protection of China. Rogan et al. [8] demonstrated that the heavy metal contamination of paddy soils and rice from Kočani field (eastern Macedonia) resulted from irrigation with riverine water that was impacted by past and present base-metal mining activities and acid mine drainage. Very high concentrations of $\mathrm{As}, \mathrm{Cd}, \mathrm{Cu}, \mathrm{Pb}$ and $\mathrm{Zn}$ were found in the paddy soils $(47.6,6.4,99,983$ and $1.245 \mu \mathrm{g} / \mathrm{g})$ and rice $(0.53,0.31,5.8,0.5$ and $67 \mu \mathrm{g} / \mathrm{g})$ in the western part of Koc `ani field. Hence, it is necessary to determine the degree of heavy metal pollution in farmland to avoid excessive heavy metal enrichment in rice.
If plants are stressed at seed germination by heavy metals, the quality of seed germination directly affects the quality and yield of crops [9]. Low concentrations of heavy metals can promote the germination of crop seeds, while high concentrations will inhibit their germination [10]. Under the same conditions, different tissues of the same variety have different physiological and biochemical mechanisms for absorbing heavy metals due to the differences in their external morphology and internal structure, and the accumulation of heavy metals in these tissues is quite different. Zhang et al. [11] reported that heavy metal accumulation varied among plant organs and that accumulation decreased in the order roots $>$ stems $>$ leaves. The bioaccumulation factor $(\mathrm{BCF})$ results revealed that during the grainfilling stage, the rice had high $\mathrm{BCF}$ values $(>1)$ for $\mathrm{Cd}$ and $\mathrm{Zn}$. Heavy metals in the environment can enter the human body through respiratory tract inhalation, skin contact, diet, etc., and food consumption is the main absorption pathway. Lan et al. [12] assessed the human health risk from heavy metals $(\mathrm{Pb}, \mathrm{Zn}, \mathrm{Cu}, \mathrm{Cd}$ and $\mathrm{As})$ in rice grains collected from a mining-impacted and a noncontaminated area in South Hunan Province using an in vitro simulation method. Chen et al. [13] investigated the uptake and accumulation of $\mathrm{Cd}$ by leek and rape. The bioavailability of $\mathrm{Cd}$ in human gastric juice and the human health risk from $\mathrm{Cd}$ in vegetables grown in Cd-polluted soil and soil remediated with amendments (zeolite + earthworm attapulgite + earthworm manure) were determined using an in vitro simulation test and a health risk assessment, respectively.

To evaluate the level of heavy metal pollution in soil, it is necessary to consider human activity as well as the geochemical background values of the metals. Additionally, natural diagenesis may cause changes in background values. The geo-accumulation index proposed by Muller (1969) [14] takes this factor into account, thereby addressing a shortcoming of other evaluation indexes, e.g. potential ecological hazard index [15], enrichment factor [16] and Nemero comprehensive index [17], etc. The geo-accumulation index method is extensively used to assess heavy metal pollution in soils since the method considers the influence of the geological background [14]. Additionally, heavy metals enter the body and affect human health via ingestion, inhalation and dermal contact. The health risk assessment model is able to assess the health risk from individual heavy metals based on these three pathways (non-carcinogenic risk and carcinogenic risk) [18]. Therefore, this study aimed to (1) evaluate the level of heavy metal pollution in a paddy soil in a Nanjing suburb by the geo-accumulation index method; (2) study the heavy metal concentrations in rice roots using the bio-concentration factor; (3) assess the cumulative carcinogenic and non-carcinogenic risks via health risk assessment; and (4) investigate the inadvertent ingestion of heavy metals by humans through rice based on in vitro tests. 


\section{Methods and Materials}

\section{Study Area}

Xugao village, southwest of Hengxi street, Jiangning district, Nanjing city, was selected as the study area. This area has a subtropical monsoon climate with abundant rainfall, and the rainfall is unevenly distributed in four seasons. In the winter half-year (October to March), the rainfall is affected by the cold polar continental air mass; the northerly wind prevails, bringing less rainfall. In the summer half-year (April to September), the rainfall is affected by tropical or subtropical marine air masses, with prevailing southerly winds that bring abundant precipitation. There are four types of vegetation in the study area, viz. cultivated, mountain forest, swamp and aquatic vegetation, and the agricultural cultivated vegetation area is the largest. Mountain forest, swamp and aquatic vegetation are natural vegetation types.

\section{Sample Collection and Preparation}

Lianjing2 (one of the main local rice cultivars) was bred in 1992 by the Lianyungang Institute of Agricultural Sciences using a medium-variation single Taiwan rice plant. This rice variety grows to approximately $109 \mathrm{~cm}$, has short sword leaves and exhibits strong tillering. The total number of grains per panicle is approximately 115 , and the seed setting rate is approximately $90 \%$. The 1000 -grain weight is $27 \mathrm{~g}$ and the rice quality is good; however, it is difficult to thresh. Soil samples $(0-20-\mathrm{cm}$ depth) were obtained from the rice rhizosphere before sowing (May 2019) and at the harvesting stage (September 2019). Five sampling points were selected and located with GPS tools. Five samples were collected from each sample site. The soil type throughout the study area is a calcareous soil. The soil samples were labelled as follows:

\begin{tabular}{|c|}
\hline 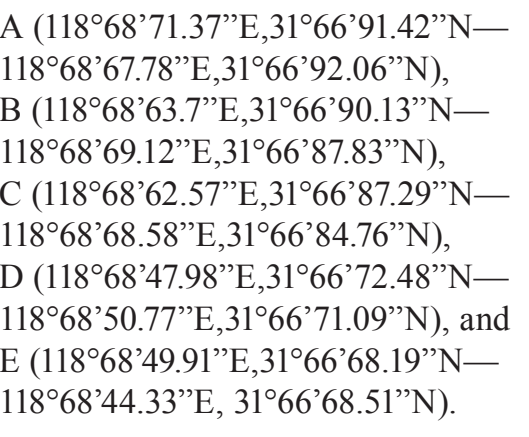 \\
\hline \\
\hline
\end{tabular}

\section{Heavy Metal Concentration Analysis}

The $\mathrm{pH}$ values of the soils were determined in a soil:water (1:2.5) suspension [19]. The redox potential (Eh) of the soil was measured using a $\mathrm{pH}$ meter with a platinum electrode [20]. The organic matter (OM) content of the soils was determined using the potassium dichromate external heating method [21]. The Cr,
$\mathrm{Cd}, \mathrm{Pb}, \mathrm{Cu}$ and $\mathrm{Zn}$ in the soil and rice samples were digested using $\mathrm{HNO}_{3}-\mathrm{HF}-\mathrm{H}_{2} \mathrm{O}_{2}$, and the $\mathrm{Hg}$ and $\mathrm{As}$ in the soil were digested with aqua regia. $\mathrm{HNO}_{3}-\mathrm{H}_{2} \mathrm{O}_{2}$ (3:1) was used to digest the $\mathrm{Hg}$ and $\mathrm{As}$ in rice under high-pressure, airtight conditions. Tessier's five-stage sequential extraction procedure was employed to determine the chemical speciation of the heavy metals in the soils. The total contents of the heavy metals $(\mathrm{Cr}$, $\mathrm{Cd}, \mathrm{Pb}, \mathrm{Cu}$ and $\mathrm{Zn}$ ) in the aforementioned digested soil and rice samples were measured using inductively coupled plasma optical emission spectrometry. The concentrations of metalloids ( $\mathrm{Hg}$ and $\mathrm{As}$ ) in the soil and rice were determined using a nondispersive atomic fluorescence spectrometer (AFS-933, Beijing Jitian Instrument Co., Ltd.).

The vessels used were soaked in $25 \%-30 \% \mathrm{HNO}_{3}$ for longer than $8 \mathrm{~h}$ and repeatedly washed with deionized water. Certified standard reference materials (GSS-3) purchased from the State Bureau of Technical Supervision of China were used to ensure the accuracy and precision of the methods and results. The recovery rate of the heavy metals in the soil and rice samples ranged from $86.73 \%$ to $109.17 \%$.

\section{Risk Assessment Methods}

\section{Geo-Accumulation Index for the Evaluation of Heavy Metal Pollution in Soils}

The geo-accumulation index $\left(\mathrm{I}_{\text {geo }}\right)$ is used to evaluate the cumulative heavy metal pollution in soil [22]. This index considers the influence of human pollution factors and environmental geochemistry on the background value of heavy metal as well as the variations in the background value caused by geological differences in different places [23]. The equation is as follows:

$$
\mathrm{I}_{\mathrm{geo}}=\log _{2}\left(\frac{C_{\mathrm{i}}}{1.5 B_{\mathrm{n}}}\right)
$$

...where $\mathrm{C}_{\mathrm{i}}$ is the determined concentration of heavy metal $i$ in the soil and $B_{\mathrm{n}}$ is the local geochemical background value for the heavy metal. The $B_{\mathrm{n}}$ values were obtained by referring to the Soil Environment Quality Risk Control Standard for Soil Contamination of Agricultural Land in China (GB15618-2018). The constant 1.5 was employed because of the natural fluctuation of the baseline data. $I_{\text {geo }}$ has seven classes: uncontaminated $\left(\mathrm{I}_{\mathrm{geo}} \leq 0\right)$, uncontaminated to moderately contaminated $\left(0<\mathrm{I}_{\text {geo }} \leq 1\right)$, moderately contaminated $\left(1<\mathrm{I}_{\text {geo }} \leq 2\right)$, moderately to heavily contaminated $\left(2<\mathrm{I}_{\text {geo }}^{\mathrm{geo}} \leq 3\right)$, heavily contaminated $(3<\operatorname{Igeo} \leq 4)$, heavily to extremely contaminated $\left(4<\mathrm{I}_{\text {geo }} \leq 5\right)$ and extremely contaminated $\left(\mathrm{I}_{\mathrm{geo}}>5\right)$.

The bio-concentration factor (BCF) of heavy metals is the ratio of the content of a heavy metal in part of the plant to the content of the same heavy metal in the soil [24]. This reflects the ability of the heavy metal 
to migrate within the sediment-plant system and thus indicates the enrichment of the heavy metals in the plant.

$$
B C F=\frac{M \text { etal }_{\text {root }}}{M \text { etal }_{\text {soil }}}
$$

...where Metal ${ }_{\text {soil }}$ and Metal ${ }_{\text {root }}$ are the concentrations of heavy metals in the rhizosphere soil and roots of rice (dry soil), respectively.

\section{Health Risk Assessment}

Generally, individuals are exposed to metals in soils by three main pathways, i.e., ingestion, inhalation and dermal contact [25]. The health risk assessment performed in this study is based on those developed by the United States Environmental Protection Agency for health risk assessment and the Dutch National Institute of Public Health Agency, which can calculate the exposure risks to adults or children from soil metals [26]. The equations are as follows:

$$
C D I_{\text {ing-nc }}\left(\mathrm{mg} \cdot \mathrm{kg}^{-1} \cdot \mathrm{day}^{-1}\right)=\frac{C \times \operatorname{Ing} R \times E F \times E D}{B W \times A T_{\mathrm{nc}} \times 10^{6}}
$$

$$
C D I_{\text {inh-nc }}\left(\mathrm{mg} \cdot \mathrm{m}^{-3}\right)=\frac{C \times E F \times E T \times E D}{P E F \times 24 \times A T_{\mathrm{nc}}}
$$

$$
C D I_{\text {dermal-nc }}\left(\mathrm{mg} \cdot \mathrm{kg}^{-1} \cdot \mathrm{day}^{-1}\right)=\frac{C \times S A \times A F \times A B S_{\mathrm{d}} \times E F \times E D}{B W \times A T_{\mathrm{nc}} \times 10^{6}}
$$

$$
H I=\sum H Q=H Q_{\text {ing }}+H Q_{\text {inh }}+H Q_{\text {dermal }}
$$

$$
H I=\frac{C D I_{\text {ing-nc }}}{R_{\mathrm{f}} D_{\text {ing }}}+\frac{C D I_{\text {inh-nc }}}{R_{\mathrm{f}} C_{\text {inh }}}+\frac{C D I_{\text {dermal-nc }}}{R_{\mathrm{f}} D_{\text {ing }} \times A B S_{G I}}
$$

$$
C R=L A D D \times C S F
$$

...where $\mathrm{CDI}_{\text {ing }}, \mathrm{CDI}_{\text {dermal }}$ and $\mathrm{CDI}_{\text {inh }}$ are the average daily intake from soil ingestion, dermal contact and inhalation contact, respectively $(\mathrm{mg} / \mathrm{kg} \cdot \mathrm{day}) ; \mathrm{C}$ is the average concentration of a heavy metal in topsoil $(\mathrm{mg} / \mathrm{kg})$; and IngR (mg/day) is the daily ingestion of soil. EF is the exposure duration frequency (365 days/year); ED is the exposure duration (year); BW is the body weight of the

\begin{tabular}{|c|c|c|c|c|}
\hline \multirow{2}{*}{ Description } & \multirow{2}{*}{ Parameters } & \multicolumn{2}{|c|}{ Values } & \multirow{2}{*}{ References } \\
\hline & & Children & Adults & \\
\hline Ingestion rate of soil & $\operatorname{IngR}$ (mg/day) & 200 & 100 & {$[11]$} \\
\hline Skin area available for soil contact & $\mathrm{SA}\left(\mathrm{m}^{2} /\right.$ evevt $)$ & 2800 & 5700 & {$[11]$} \\
\hline Soil-to-skin adherence factor & $\mathrm{AF}\left(\mathrm{mg} / \mathrm{cm}^{2}\right)$ & 0.20 & 0.07 & {$[11]$} \\
\hline Dermal absorption factor $(\mathrm{Cr})$ & $\mathrm{ABS}_{\mathrm{Cr}}$ & 0.04 & & {$[27]$} \\
\hline Dermal absorption factor $(\mathrm{Cd})$ & $\mathrm{ABS}_{\mathrm{Cd}}$ & 0.14 & & {$[27]$} \\
\hline Dermal absorption factor $(\mathrm{Pb})$ & $\mathrm{ABS}_{\mathrm{Pb}}$ & 0.006 & & {$[27]$} \\
\hline Dermal absorption factor ( $\mathrm{Zn})$ & $\mathrm{ABS}_{\mathrm{Zn}}$ & 0.02 & & {$[27]$} \\
\hline Dermal absorption factor $(\mathrm{Cu})$ & $\mathrm{ABS}_{\mathrm{Cu}}$ & 0.10 & & {$[27]$} \\
\hline Particle emission factor & PEF $\left(\mathrm{m}^{3} / \mathrm{kg}\right)$ & $1.36 \times 10^{9}$ & & {$[11]$} \\
\hline Exposure time & ET(h/day) & 24 & & {$[11]$} \\
\hline Exposure frequency & EF (day/year) & 350 & & {$[11]$} \\
\hline Exposure duration & ED (year) & 6 & 30 & {$[11]$} \\
\hline Body weight & BW (kg) & 16.2 & 61.8 & {$[11]$} \\
\hline Average time for carcinogenic & ATca (day) & $\mathrm{LT} \times 365$ & & {$[11]$} \\
\hline Average time for non-carcinogenic & ATnc (day) & $\mathrm{ED} \times 365$ & & {$[11]$} \\
\hline Life time expressed in day & LT (day) & 72 & & {$[27]$} \\
\hline
\end{tabular}
exposed individual $(\mathrm{kg})$; and AT is the time period over which the dose is averaged (day); and $\mathrm{R}_{\mathrm{f}} \mathrm{D}$ is the chronic reference dose for a heavy metal $(\mathrm{mg} / \mathrm{kg} \cdot$ day). A hazard index (HI) approach was applied to assess the overall potential for non-carcinogenic effects posed by more

Table 1. Parameters for health risk assessment. 
Table 2. Toxicological parameters for different heavy metals of health risk assessment [11].

\begin{tabular}{|c|c|c|c|}
\hline \multirow{2}{*}{} & \multirow{2}{*}{ ABSGI } & RSC $_{\text {inh }}$ & RfD $_{\text {ing }}$ \\
\cline { 3 - 4 } & & $\mathrm{mg} / \mathrm{kg} /$ day & $\mathrm{mg} / \mathrm{m}^{3}$ \\
\hline $\mathrm{As}$ & 1 & $3.00 \mathrm{E}-04$ & $3.00 \mathrm{E}-04$ \\
\hline $\mathrm{Cd}$ & 0.025 & $1.00 \mathrm{E}-03$ & $2.50 \mathrm{E}-05$ \\
\hline $\mathrm{Cr}$ & 0.013 & $1.50 \mathrm{E}+00$ & $1.95 \mathrm{E}-02$ \\
\hline $\mathrm{Cu}$ & 1 & $4.00 \mathrm{E}-02$ & $4.00 \mathrm{E}-02$ \\
\hline $\mathrm{Hg}$ & 1 & $1.60 \mathrm{E}-04$ & $1.60 \mathrm{E}-04$ \\
\hline $\mathrm{Ni}$ & 0.04 & $2.00 \mathrm{E}-02$ & $8.00 \mathrm{E}-04$ \\
\hline $\mathrm{Pb}$ & 1 & $1.40 \mathrm{E}-04$ & $1.40 \mathrm{E}-04$ \\
\hline $\mathrm{Zn}$ & 1 & $3.00 \mathrm{E}-01$ & $3.00 \mathrm{E}-01$ \\
\hline
\end{tabular}

than one chemical (Tables 1 and 2). If the HI is less than 1, no risk of adverse health effects is indicated. If the HI is $>1$, non-carcinogenic effects are possible [27].

The carcinogenic risk (CR), which reflects the lifetime cancer risk for an individual, can be determined by multiplying the lifetime average daily dose (LADD) by the cancer slope factor. The calculations of LADD were made with equations 5-7 using the dose averaged over a lifetime (LT) instead of AT. The CSF values of $\mathrm{As}, \mathrm{Cd}, \mathrm{Cr}$ and $\mathrm{Pb}$ are 1.5, 6.3, 0.5, and $0.0085 \mathrm{per}(\mathrm{mg} / \mathrm{kg} / \mathrm{day})^{-1}$, respectively [28]. A value of $1 \times 10^{-6}<\mathrm{CR}<1 \times 10^{-4}$ signifies an acceptable risk, and a value of $\mathrm{CR}>1 \times 10^{-4}$ indicates high risk of cancer.

\section{In-vitro Simulation Test}

An improved version of the in vitro simulation method of Ruby [29] and Rodriguez [30] was used in this study [12]. In the simulated stomach stage, $4 \mathrm{~L}$ of simulated gastric juice was prepared, containing $0.15 \mathrm{mmol} / \mathrm{L} \mathrm{NaCl}, 2.00 \mathrm{~g}$ citric acid, $2.00 \mathrm{~g}$ malic acid, $1.68 \mathrm{~mL}$ lactic acid, $2.00 \mathrm{~mL}$ acetic acid and $5 \mathrm{~g}$ pepsin. The $\mathrm{pH}$ value of the solution was adjusted to $1.50 \mathrm{using}$ $12.00 \mathrm{~mol} / \mathrm{L} \mathrm{HCl}$. An amount of $600 \mathrm{~mL}$ simulated gastric juice was added to six reactors, and $6.00 \mathrm{~g}$ rice was added to each reactor through a $0.25 \mathrm{~mm}$ sieve. Argon was introduced into the reaction liquid at a rate of $1.00 \mathrm{~L} / \mathrm{min}$ to create an anaerobic environment, and the mixtures were stirred at $100.00 \mathrm{r} / \mathrm{min}$ for $1.0 \mathrm{~h}$. After that, $20 \mathrm{~mL}$ of the reaction solution was extracted with a syringe, centrifuged at $10000 \mathrm{r} / \mathrm{min}$, and filtered with a $0.45 \mu \mathrm{m}$ membrane. The contents of $\mathrm{Pb}, \mathrm{Zn}, \mathrm{Cu}$, and $\mathrm{Cd}$ in the filtrate were analysed by ICP-MS.

In the simulated intestinal stage, the $\mathrm{pH}$ value of the reaction solution was adjusted to 8.0 using a saturated solution of $\mathrm{NaHCO}_{3}$. Trypsin (0.36 g), bile salt (20 g), and $\operatorname{argon}(1.00 \mathrm{~L} / \mathrm{min})$ were added to each reactor, and the mixtures were stirred for $4.0 \mathrm{~h}$ at $100 \mathrm{r} / \mathrm{min}$. The $\mathrm{pH}$ value of the reaction solution was determined every $15 \mathrm{~min}$. To maintain the $\mathrm{pH}$ value at 8.0 , when the $\mathrm{pH}$ value increased, $\mathrm{HCl}$ at $12.00 \mathrm{~mol} / \mathrm{L}$ was added to the solution. After the start of the small intestine stage, $20.00 \mathrm{~mL}$ of the reaction solution was taken after $4.0 \mathrm{~h}$, centrifuged at $10000.00 \mathrm{r} / \mathrm{min}$ and filtered through a $0.45 \mu \mathrm{m}$ membrane. The contents of $\mathrm{Pb}, \mathrm{Zn}, \mathrm{Cu}$, and $\mathrm{Cd}$ in the filtrate were determined by ICP-MS.

The bioavailability of $\mathrm{Pb}, \mathrm{Zn}, \mathrm{Cu}$, and $\mathrm{Cd}$ in the rice at the simulated gastric and intestinal stages was calculated by equation (9):

$$
B A=\frac{C_{1} V_{1}}{C_{\mathrm{s}} \mathrm{m}_{\mathrm{s}}} \times 100 \%
$$

...where BA is the bioavailability of heavy metals absorbed by rice, $\% ; \mathrm{C}_{1}$ is the total soluble amount of heavy metals in the reaction solution of the gastric or small intestine stage, $\mathrm{mg} / \mathrm{L} ; \mathrm{V}$ is the volume of the reaction solution in each reactor, $\mathrm{L} ; \mathrm{C}_{\mathrm{s}}$ is the total amount of heavy metals in the rice sample, $\mathrm{mg} / \mathrm{kg}$; and $m_{\mathrm{s}}$ is the mass of the rice sample added to the reactor, $\mathrm{kg}$. The daily average heavy metal intake through the soil-human pathway is calculated as follows:

$$
W_{\mathrm{m}}=C_{\mathrm{m}} \times \mathrm{W}_{\text {soil }}
$$

...where $W_{\mathrm{m}}$ is the amount of the heavy metal absorbed by eating rice, $\mu \mathrm{g} / \mathrm{d} ; \mathrm{C}_{\mathrm{m}}$ is the content of the heavy metal in rice, $\mathrm{mg} / \mathrm{kg}$; and $\mathrm{W}$ is the daily rice consumption ( $389 \mathrm{~g} / \mathrm{d}$ for adults and $277 \mathrm{~g} / \mathrm{d}$ for children).

The amount heavy metals absorbed into the body through rice was calculated by equation (11).

$$
W_{A}=W_{\mathrm{m}} \times \mathrm{BA}
$$

...where $W_{\mathrm{A}}$ is the amount of heavy metals that can be absorbed every day, $\mu \mathrm{g} / \mathrm{d} ; W_{\mathrm{m}}$ is the intake of heavy metals; $\mu \mathrm{g} / \mathrm{d}$; and $B A$ is the bioavailability of specific heavy metals, $\%$.

\section{Results and Discussion}

\section{Level of Heavy Metal Pollution in Rice Soil}

Before rice sowing and at rice harvesting, the $\mathrm{pH}$ values of the soils ranged from 7.93 to 8.14 and 7.91 to 8.04, respectively. Rice, an acid-loving crop, can grow under acidic conditions, at $\mathrm{pH}$ 4.5-5.5. The $\mathrm{pH}$ value of paddy soils should be between 6.0 and 7.5 [31]. The nutrients needed by plants are most effective in soils within this $\mathrm{pH}$ range, which is conducive to nutrient absorption and utilization by plants. A $\mathrm{pH}$ value below 5.5 is not conducive to the absorption of calcium or magnesium. If the $\mathrm{pH}$ value is excessively high or low, it is not beneficial to the growth of plants; under these conditions, plants are prone to symptoms of nutrient deficiency, e.g., stunted growth, yellowed young leaves, 
withered or scorched leaf margins, and rotten capillary roots [32]. In addition, the soil Eh was between -154.70 to $-144.00 \mathrm{mV}$ and -189.50 to $-180.60 \mathrm{mV}$ during the two stages, respectively. The reduction in Eh intensity may result in the production of various sulfides. Hence, draining and drying the field in time can improve the Eh value of soil.

The concentrations of $\mathrm{Cr}, \mathrm{Cd}, \mathrm{Pb}, \mathrm{Cu}, \mathrm{Zn}, \mathrm{Hg}$ and As in soil of study area at the before sowing of rice were $84.51 \pm 3.19, \quad 1.15 \pm 0.17,50.48 \pm 3.44,27.05 \pm 0.35$, $70.00 \pm 0.65, \quad 0.29 \pm 0.02$ and $15.41 \pm 0.09 \mathrm{mg} / \mathrm{kg}$, respectively. However, the concentrations of $\mathrm{Cr}, \mathrm{Cd}$, $\mathrm{Pb}, \mathrm{Cu}, \mathrm{Zn}, \mathrm{Hg}$ and $\mathrm{As}$ in soil of study area at the before sowing of rice were $49.19 \pm 1.35,0.48 \pm 0.08$, $55.74 \pm 3.03, \quad 13.03 \pm 0.73, \quad 78.29 \pm 1.95, \quad 0.16 \pm 0.01$ and $7.72 \pm 4.07 \mathrm{mg} / \mathrm{kg}$, respectively. The $\mathrm{I}_{\text {geo }}$ values of $\mathrm{Cd}$ were significantly higher than those of the other heavy metals and metalloids during the two stages in this study. This may be because it is of higher ecotoxicity [33] and the value of $\mathrm{Cd}$ in soil of study area were near the limit for Cd content proposed by GB15618-2018. In both stages, the order of $\mathrm{I}_{\text {geo }}$ values (except those of $\mathrm{Pb}$ and $\mathrm{Zn}$ ) was $\mathrm{Cd}>\mathrm{As}>\mathrm{Hg}>\mathrm{Cu}>\mathrm{Cr}$. Moreover, the metals with the lower $\mathrm{I}_{\text {geo }}$ values exhibited a low risk at both stages in the study areas (Fig. 1). Fig. 2a) shows the content of the five species (residual, organic matterbound, iron-manganese oxide-bound, exchangeable and carbonate-bound) of heavy metals in soils during the two stages. The content of the chemical species of $\mathrm{Cr}$ in soil before rice sowing and at the rice harvesting stage was as follows: residual $>$ organic matter-bound $>$ iron-manganese oxide-bound $>$ exchangeable $>$ carbonatebound (Fig. 2b). Similarly, the percentages of residual $\mathrm{As}, \mathrm{Zn}$ and $\mathrm{Hg}$ were higher than those of the other species of these metals. In addition, the percentages of residual $\mathrm{Cd}, \mathrm{Pb}$ and $\mathrm{Cu}$ decreased significantly between the two stages, and the percentages of their ironmanganese oxide-bound species increased. Generally, the content of the iron-manganese oxide-bound species in soils before rice sowing was higher than that at the

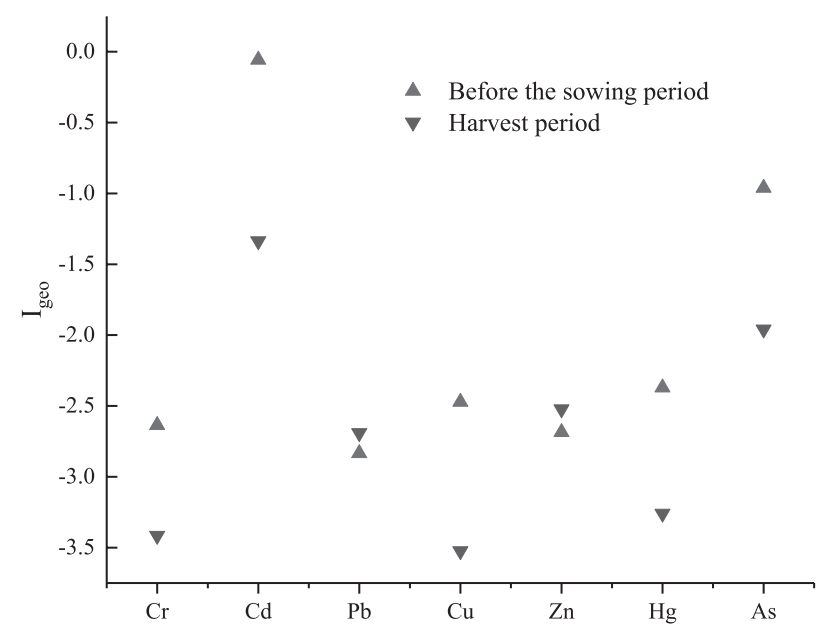

Fig. 1 The $I_{\text {geo }}$ values of heavy metals in soil at the different growth periods of rice.
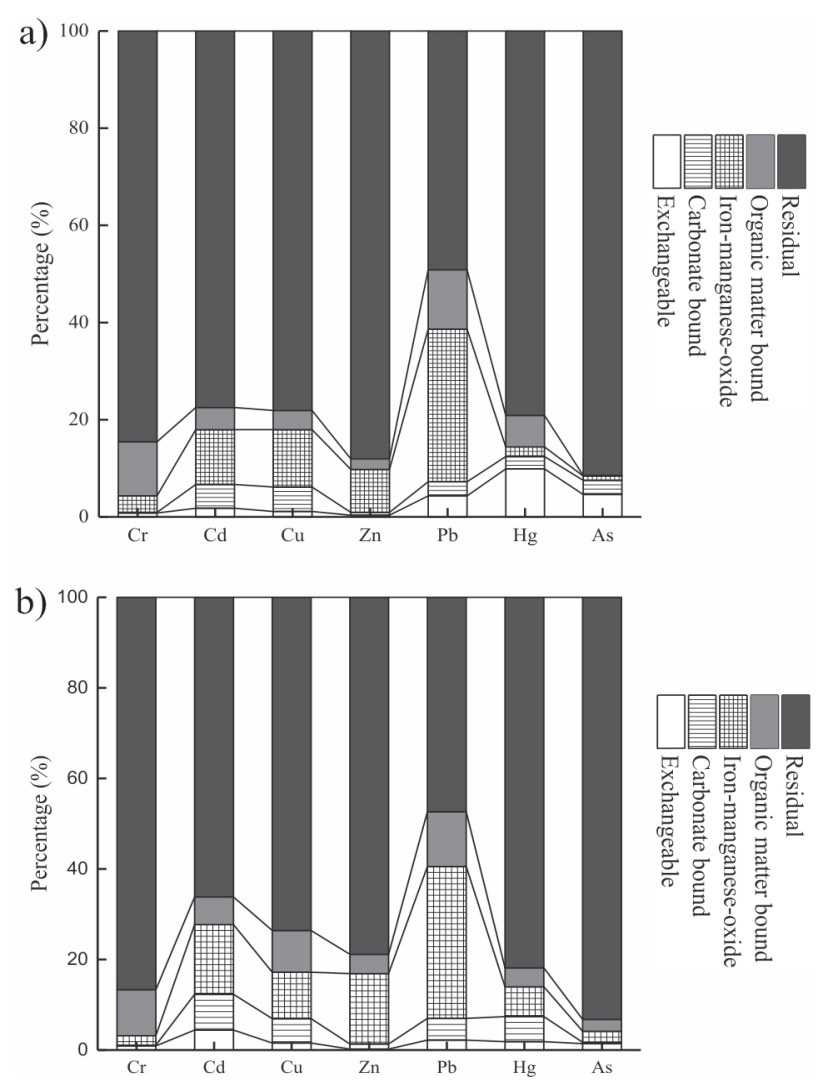

Fig 2. The concentration of heavy metal speciation in soil at the before sowing a) and harvesting b) periods of rice.

rice harvesting stage, which may be due to the fertilizer applied in the process of planting rice. In both stages, the content of the exchangeable species of the heavy metals was the lowest of all chemical species. The exchangeable state of heavy metals is easily absorbed by rice, thus, the low levels of exchangeable heavy metals may have led to a lower concentration being adsorbed in the local rice. Therefore, the farmland in the study area was not polluted by heavy metals based on the evaluation of their total content and chemical speciation.

\section{Bio-Concentration Factors in the Rice-Soil System}

Table 3 shows the concentrations of heavy metals in different tissues of rice and their BCF values. The order of $\mathrm{Cr}$ content in the different rice tissues was root $>$ leaves $>$ grain $>$ stem $>$ rice husk $>$ polished roundgrained rice. The $\mathrm{BCF}$ values of $\mathrm{Cr}$ were 0.0403 and 0.2940 , respectively. The alkaline soil in the study area can significantly affect the speciation of $\mathrm{Cr}$ in soils. The higher $\mathrm{pH}$ values of soils in the study area can significantly affect the speciation of $\mathrm{Cr}$. Lower $\mathrm{pH}$ value in soils transform $\mathrm{Cr}(\mathrm{VI})$ into stable $\mathrm{Cr}(\mathrm{III})$, which can reduce the migration capacity and toxicity of $\mathrm{Cr}$ in soils [34]. In contrast, a higher $\mathrm{pH}$ value in soils is conducive to the formation of $\mathrm{Cr}(\mathrm{IV})$, especially in alkaline soils. 
Table 3. The concentration of heavy metals of roots, stem, leaves, grain, rice husk and polished round-grained rice.

\begin{tabular}{|c|c|c|c|c|c|c|c|}
\hline & $\begin{array}{c}\text { Root } \\
(\mathrm{mg} / \mathrm{kg})\end{array}$ & $\begin{array}{l}\text { Stem } \\
(\mathrm{mg} / \mathrm{kg})\end{array}$ & $\begin{array}{l}\text { Leaves } \\
(\mathrm{mg} / \mathrm{kg})\end{array}$ & $\begin{array}{l}\text { Grain } \\
(\mathrm{mg} / \mathrm{kg})\end{array}$ & $\begin{array}{c}\text { Rice husk } \\
(\mathrm{mg} / \mathrm{kg})\end{array}$ & $\begin{array}{l}\text { Polished round-grained } \\
\text { rice }(\mathrm{mg} / \mathrm{kg})\end{array}$ & $\mathrm{BCF}$ value \\
\hline $\mathrm{Cr}$ & $\begin{array}{c}1.98 \\
\pm 0.08\end{array}$ & $\begin{array}{c}0.43 \\
\pm 0.38\end{array}$ & $\begin{array}{c}0.58 \\
\pm 0.02\end{array}$ & $\begin{array}{c}0.53 \\
\pm 0.06\end{array}$ & $\begin{array}{c}0.22 \\
\pm 0.03\end{array}$ & $\begin{array}{c}0.21 \\
\pm 0.03\end{array}$ & 0.04 \\
\hline $\mathrm{Cd}$ & $\begin{array}{c}1.50 \\
\pm 0.13\end{array}$ & $\begin{array}{c}0.09 \\
\pm 0.02\end{array}$ & $\begin{array}{c}0.19 \\
\pm 0.03\end{array}$ & $\begin{array}{c}0.17 \\
\pm 0.004\end{array}$ & $\begin{array}{c}0.08 \\
\pm 0.01\end{array}$ & $\begin{array}{c}0.10 \\
\pm 0.01\end{array}$ & 3.16 \\
\hline $\mathrm{Pb}$ & $\begin{array}{l}13.75 \\
\pm 0.75\end{array}$ & $\begin{array}{c}3.19 \\
\pm 0.15\end{array}$ & $\begin{array}{c}1.43 \\
\pm 0.21\end{array}$ & $\begin{array}{c}3.57 \\
\pm 0.37\end{array}$ & $\begin{array}{c}1.35 \\
\pm 0.28\end{array}$ & $\begin{array}{c}1.22 \\
\pm 0.55\end{array}$ & 0.25 \\
\hline $\mathrm{Zn}$ & $\begin{array}{l}22.24 \\
\pm 0.60\end{array}$ & $\begin{array}{l}13.30 \\
\pm 1.60\end{array}$ & $\begin{array}{l}13.80 \\
\pm 0.74\end{array}$ & $\begin{array}{l}24.06 \\
\pm 1.52\end{array}$ & $\begin{array}{c}8.61 \\
\pm 0.94\end{array}$ & $\begin{array}{c}8.44 \\
\pm 0.94\end{array}$ & 0.28 \\
\hline $\mathrm{Cu}$ & $\begin{array}{c}5.52 \\
\pm 0.80\end{array}$ & $\begin{array}{c}1.13 \\
\pm 0.13\end{array}$ & $\begin{array}{c}3.14 \\
\pm 0.13\end{array}$ & $\begin{array}{c}3.13 \\
\pm 0.02\end{array}$ & $\begin{array}{c}1.51 \\
\pm 0.04\end{array}$ & $\begin{array}{c}1.62 \\
\pm 0.05\end{array}$ & 0.42 \\
\hline $\mathrm{Hg}$ & $\begin{array}{c}0.004 \\
\pm 0.004\end{array}$ & $\begin{array}{c}0.002 \\
\pm 0.005\end{array}$ & $\begin{array}{c}0.002 \\
\pm 0.006\end{array}$ & $\begin{array}{l}0.002 \\
\pm 0.01\end{array}$ & $\begin{array}{l}0.002 \\
\pm 0.01\end{array}$ & $\begin{array}{c}0.002 \\
\pm 0.001\end{array}$ & 0.03 \\
\hline As & $\begin{array}{c}0.52 \\
\pm 0.09\end{array}$ & $\begin{array}{c}0.01 \\
\pm 0.07\end{array}$ & $\begin{array}{c}0.21 \\
\pm 0.10\end{array}$ & $\begin{array}{c}0.28 \\
\pm 0.07\end{array}$ & $\begin{array}{l}0.30 \\
\pm 0.8\end{array}$ & $\begin{array}{c}0.42 \\
\pm 0.12\end{array}$ & 0.07 \\
\hline
\end{tabular}

All values are mean of three replicates $(n=3)$.

The overall order of $\mathrm{Cd}$ accumulation in the different tissues was root $>$ leaves $>$ stem. The concentration of $\mathrm{Cd}$ in rice roots was generally $5-63 \mathrm{mg} / \mathrm{kg}$ in farmland polluted by heavy metals [35]. The Cd content in this study was only $1.50 \mathrm{mg} / \mathrm{kg}$, and there was no pollution by heavy metals according to the evaluation of geoaccumulation index. The $\mathrm{BCF}$ value of $\mathrm{Cd}$ in rice was 3.158. The urinary system will be damaged if excessive $\mathrm{Cd}$ accumulates in the kidney. The main manifestation of renal damage is proximal tubular dysfunction, which is not fatal but may slightly affect life expectancy. The $\mathrm{pH}$ value is one of the most important factors affecting the amount of $\mathrm{Cd}$ adsorbed by rice roots. It was reported in a previous study that the quality of $\mathrm{Cd}$ absorbed by plants was negatively correlated with the $\mathrm{pH}$ value of the soil within a certain range of $\mathrm{pH}$ values. In addition, $\mathrm{Cd}$ mainly exists in the form of watersoluble $\mathrm{Cd}$. On the root surface, $\mathrm{Cd}$ ions compete with $\mathrm{H}^{+}$for binding sites. The root surface releases positive ion binding sites with the increase in $\mathrm{pH}$ value, resulting in more $\mathrm{Cd}$ binding and absorption [36]. The redox value (Eh) was also one of the main factors affecting the bioavailability of $\mathrm{Cd}$ in soil. The content of watersoluble $\mathrm{Cd}$ in soil, the total amount of $\mathrm{Cd}$ absorbed by rice and the amount of $\mathrm{Cd}$ above ground increased with the increase in the Eh value in paddy fields. When the soil was in a reduction state, the amount of sulfur reduced to $\mathrm{S}^{2-}$ increased with the decrease in redox potential and precipitated with $\mathrm{Fe}, \mathrm{Cd}$ and $\mathrm{Hg}$ ions in the soil, thus reducing the concentration of heavy metal elements in the soil solution [37]. This may be the reason why the proportion of residual $\mathrm{Cd}$ was lower than that of the residual fractions of other heavy metals.

The order of $\mathrm{Pb}$ accumulation in the different tissues of rice was root $>$ stem $>$ leaves. The $\mathrm{BCF}$ values for $\mathrm{Pb}$ were lower than those for the other heavy metals; these results may be due to the lower mobility of $\mathrm{Pb}$ in the soil and the few exchangeable states of lead in the soil. It was reported that the contribution of $\mathrm{Pb}$ adsorption and absorption to the accumulation of lead in plants was much greater than that of root absorption and transportation to the upper part of the ground in some areas with high concentrations of atmospheric $\mathrm{Pb}$ [38]. $\mathrm{Pb}$ is absorbed by rice roots that take up the dissolved $\mathrm{Pb}$ ions in the soil solution; hence, the exchange state of $\mathrm{Pb}$ before rice sowing was higher than that at the rice harvesting stage. The $\mathrm{BCF}$ values of $\mathrm{Zn}, \mathrm{Cu}, \mathrm{Hg}$ and As were similar and are discussed simultaneously in this work. The $\mathrm{BCF}$ values of $\mathrm{Zn}, \mathrm{Cu}, \mathrm{Hg}$ and As were $0.2841,0.4238,0.0268$ and 0.0668 , respectively, and $\mathrm{Cu}$ had the highest BCF value. Lower concentrations of $\mathrm{Cu}$ can promote rice growth and development. However, $\mathrm{Cu}$ can destroy the structure and function of the rice cell membrane when its concentration exceeds the threshold value for rice growth; $\mathrm{Cu}$ affects the permeability of the rice cell membrane and damages the antioxidant enzyme system and chloroplast structure of the plant, thus inhibiting rice development [39]. According to the analysis in this study, the contents of $\mathrm{Cu}$ in the soil and plants were within the normal range. In addition, excessive $\mathrm{Zn}$ content can endanger the root system of rice and prevent the growth of the root system. In addition, brown spots and necrosis have been observed on the ground under conditions of high $\mathrm{Zn}$ concentration stress; however, this situation was not observed in this study. Finally, overall, the order of the heavy metal BCF values in rice was $\mathrm{Cd}>\mathrm{Cu}>\mathrm{Zn}>\mathrm{Pb}>\mathrm{As}>\mathrm{Cr}>\mathrm{Hg}$.

\section{Human Health Risk Assessment}

Table 4 shows the non-carcinogenic doses and hazard exposure levels of the metals in the soil samples for both children and adults. For all heavy metals, 
the noncarcinogenic doses of the different exposure pathways indicated that $\mathrm{CDI}_{\text {ing-nc }}>\mathrm{CDI}_{\text {dermal }}>\mathrm{CDI}_{\text {inh-nc }}$ for children, which may be due to the hand-to-mouth habits of children. $\mathrm{CDI}_{\text {ing-nc }}$ was clearly the main exposure pathway for local residents. Before rice sowing, the HI values of heavy metals in soil for children were significantly higher than those for adults, implying that children were more easily affected by the heavy metals in soils. Their HI value was lower in comparison with the other literature, which may be caused by main farmland and no chemical plants in the study. A similar phenomenon was also found at the rice harvesting stage, and the HI values for children were higher than those for adults. Surprisingly, in both adults and children, the HI values before rice sowing were obviously higher than those at the rice harvesting stage. This situation occurred because several heavy metal elements were absorbed by rice during the growth process, decreasing their content in soil throughout the rice growth stage. The HI values for adults and children for heavy metals before rice sowing were 0.0984 and 0.634 , respectively, indicating that these metals have little influence on the human body. The HI values for adults and children for heavy metals at the rice harvesting stage were 0.146 and 0.879 , respectively. The order of HI values at the harvesting stage was $\mathrm{Pb}>\mathrm{As}>\mathrm{Cd}>\mathrm{Hg}>\mathrm{Cr}>\mathrm{Zn}>\mathrm{Cu}$

Table 4. Non-carcinogenic doses and hazard exposure of metals in soil samples to children and adults through three routes.

\begin{tabular}{|c|c|c|c|c|c|c|c|c|}
\hline \multirow{2}{*}{ Life stages } & \multirow{2}{*}{$\begin{array}{c}\text { Non-carcinogenic } \\
\text { risks }\end{array}$} & \multicolumn{7}{|c|}{ Heavy metals } \\
\hline & & $\mathrm{Cr}$ & $\mathrm{Cd}$ & $\mathrm{Pb}$ & $\mathrm{Cu}$ & $\mathrm{Zn}$ & $\mathrm{Hg}$ & As \\
\hline \multirow{7}{*}{$\begin{array}{c}\text { Adult } \\
\text { (before sowing } \\
\text { of rice) }\end{array}$} & $\mathrm{CDI}_{\text {ing }}$ & $1.31 \mathrm{E}-04$ & $1.79 \mathrm{E}-06$ & $7.83 \mathrm{E}-05$ & 4.20E-05 & $1.09 \mathrm{E}-04$ & $4.50 \mathrm{E}-07$ & $2.39 \mathrm{E}-05$ \\
\hline & $\mathrm{CDI}_{\text {inh }}$ & $5.96 \mathrm{E}-08$ & $8.13 \mathrm{E}-10$ & $3.56 \mathrm{E}-08$ & $1.91 \mathrm{E}-08$ & 4.93E-08 & $2.04 \mathrm{E}-10$ & $1.09 \mathrm{E}-08$ \\
\hline & $\mathrm{CDI}_{\text {demal }}$ & 2.09E-05 & $1.00 \mathrm{E}-06$ & $1.88 \mathrm{E}-06$ & $1.67 \mathrm{E}-05$ & 8.66E-06 & $8.98 \mathrm{E}-08$ & $2.86 \mathrm{E}-06$ \\
\hline & $\mathrm{HQ}_{\text {ing }}$ & $8.74 \mathrm{E}-05$ & $7.16 \mathrm{E}-05$ & $7.83 \mathrm{E}-05$ & 4.20E-05 & $1.09 \mathrm{E}-04$ & $4.50 \mathrm{E}-07$ & $2.39 \mathrm{E}-06$ \\
\hline & $\mathrm{HQ}_{\text {inh }}$ & $3.97 \mathrm{E}-06$ & $3.25 \mathrm{E}-05$ & $2.54 \mathrm{E}-04$ & 4.77E-07 & $1.64 \mathrm{E}-07$ & $1.28 \mathrm{E}-06$ & $3.62 \mathrm{E}-06$ \\
\hline & $\mathrm{HQ}_{\text {demal }}$ & $1.07 \mathrm{E}-03$ & 4.00E-02 & $1.34 \mathrm{E}-02$ & 4.19E-04 & $3.62 \mathrm{E}-04$ & $2.81 \mathrm{E}-03$ & $3.97 \mathrm{E}-02$ \\
\hline & $\mathrm{HI}$ & $1.16 \mathrm{E}-03$ & 4.01E-02 & $1.37 \mathrm{E}-02$ & 4.61E-04 & 4.71E-04 & $2.81 \mathrm{E}-03$ & 3.97E-02 \\
\hline \multirow{7}{*}{$\begin{array}{c}\text { Children } \\
\text { (before sowing } \\
\text { of rice) }\end{array}$} & $\mathrm{CDI}_{\text {ing }}$ & $1.00 \mathrm{E}-03$ & $1.37 \mathrm{E}-05$ & $5.98 \mathrm{E}-04$ & $3.20 \mathrm{E}-04$ & 8.28E-04 & $3.43 \mathrm{E}-06$ & $1.82 \mathrm{E}-05$ \\
\hline & $\mathrm{CDI}_{\mathrm{inh}}$ & $3.47 \mathrm{E}-08$ & $3.35 \mathrm{E}-10$ & $3.93 \mathrm{E}-08$ & 9.19E-09 & $5.52 \mathrm{E}-08$ & $1.10 \mathrm{E}-10$ & $5.44 \mathrm{E}-09$ \\
\hline & $\mathrm{CDI}_{\text {demal }}$ & $1.12 \mathrm{E}-04$ & $1.53 \mathrm{E}-06$ & $6.69 \mathrm{E}-05$ & $3.59 \mathrm{E}-05$ & $9.28 \mathrm{E}-05$ & $3.85 \mathrm{E}-07$ & 2.04E-06 \\
\hline & $\mathrm{HQ}_{\text {ing }}$ & $6.67 \mathrm{E}-04$ & $5.46 \mathrm{E}-04$ & $5.98 \mathrm{E}-04$ & $3.20 \mathrm{E}-04$ & 8.28E-04 & $3.43 \mathrm{E}-06$ & $1.82 \mathrm{E}-05$ \\
\hline & $\mathrm{HQ}_{\mathrm{inh}}$ & $2.31 \mathrm{E}-06$ & $1.34 \mathrm{E}-05$ & $2.81 \mathrm{E}-04$ & $2.30 \mathrm{E}-07$ & $1.84 \mathrm{E}-07$ & $6.90 \mathrm{E}-07$ & $1.81 \mathrm{E}-06$ \\
\hline & $\mathrm{HQ}_{\text {demal }}$ & $5.75 \mathrm{E}-03$ & $6.12 \mathrm{E}-02$ & $4.78 \mathrm{E}-01$ & 8.97E-04 & $2.76 \mathrm{E}-03$ & $2.15 \mathrm{E}-02$ & $6.08 \mathrm{E}-02$ \\
\hline & $\mathrm{HI}$ & $6.42 \mathrm{E}-03$ & $6.17 \mathrm{E}-02$ & 4.79E-01 & $1.22 \mathrm{E}-03$ & $3.59 \mathrm{E}-03$ & $2.15 \mathrm{E}-02$ & $6.08 \mathrm{E}-02$ \\
\hline \multirow{7}{*}{$\begin{array}{c}\text { Adult } \\
\text { (Harvest stage) }\end{array}$} & $\mathrm{CD}_{\text {Iing }}$ & 7.63E-05 & 7.37E-07 & $8.65 \mathrm{E}-05$ & $2.02 \mathrm{E}-05$ & $1.21 \mathrm{E}-04$ & $2.43 \mathrm{E}-07$ & $1.20 \mathrm{E}-05$ \\
\hline & $\mathrm{CDI}_{\text {inh }}$ & $5.96 \mathrm{E}-08$ & $8.13 \mathrm{E}-10$ & $3.56 \mathrm{E}-08$ & $1.91 \mathrm{E}-08$ & 4.93E-08 & $2.04 \mathrm{E}-10$ & $1.09 \mathrm{E}-08$ \\
\hline & $\mathrm{CDI}_{\text {demal }}$ & $1.22 \mathrm{E}-05$ & $1.18 \mathrm{E}-07$ & $1.38 \mathrm{E}-05$ & $3.23 \mathrm{E}-06$ & $1.94 \mathrm{E}-05$ & $3.88 \mathrm{E}-08$ & $1.91 \mathrm{E}-06$ \\
\hline & $\mathrm{HQ}_{\text {ing }}$ & $5.09 \mathrm{E}-05$ & $2.95 \mathrm{E}-05$ & $8.65 \mathrm{E}-05$ & $2.02 \mathrm{E}-05$ & $1.21 \mathrm{E}-04$ & $2.43 \mathrm{E}-07$ & $1.20 \mathrm{E}-05$ \\
\hline & $\mathrm{HQ}_{\mathrm{inh}}$ & $3.97 \mathrm{E}-06$ & $3.25 \mathrm{E}-05$ & $2.54 \mathrm{E}-04$ & 4.77E-07 & $1.64 \mathrm{E}-07$ & $1.28 \mathrm{E}-06$ & $3.62 \mathrm{E}-05$ \\
\hline & $\mathrm{HQ}_{\text {demal }}$ & $6.25 \mathrm{E}-04$ & 4.71E-03 & $9.86 \mathrm{E}-02$ & 8.07E-05 & $4.05 \mathrm{E}-04$ & $1.52 \mathrm{E}-03$ & $3.99 \mathrm{E}-02$ \\
\hline & HI & $6.80 \mathrm{E}-04$ & 4.77E-03 & $9.89 \mathrm{E}-02$ & $1.01 \mathrm{E}-04$ & $5.27 \mathrm{E}-04$ & $1.52 \mathrm{E}-03$ & $4.00 \mathrm{E}-02$ \\
\hline \multirow{7}{*}{$\begin{array}{c}\text { Children } \\
\text { (Harvest stage) }\end{array}$} & $\mathrm{CDI}_{\text {ing }}$ & $5.82 \mathrm{E}-04$ & $5.62 \mathrm{E}-06$ & $6.60 \mathrm{E}-04$ & $1.54 \mathrm{E}-04$ & $9.27 \mathrm{E}-04$ & $1.85 \mathrm{E}-06$ & $9.14 \mathrm{E}-05$ \\
\hline & $\mathrm{CDI}_{\mathrm{inh}}$ & $3.47 \mathrm{E}-08$ & $3.35 \mathrm{E}-10$ & 3.93E-08 & 9.19E-09 & 5.52E-08 & $1.10 \mathrm{E}-10$ & $5.44 \mathrm{E}-09$ \\
\hline & $\mathrm{CDI}_{\text {demal }}$ & $6.52 \mathrm{E}-05$ & $6.30 \mathrm{E}-07$ & 7.39E-05 & $1.73 \mathrm{E}-05$ & 1.04E-04 & $2.08 \mathrm{E}-07$ & $1.02 \mathrm{E}-05$ \\
\hline & $\mathrm{HQ}_{\text {ing }}$ & $3.88 \mathrm{E}-04$ & $2.25 \mathrm{E}-04$ & $6.60 \mathrm{E}-04$ & $1.54 \mathrm{E}-04$ & $9.27 \mathrm{E}-04$ & $1.85 \mathrm{E}-06$ & $9.14 \mathrm{E}-05$ \\
\hline & $\mathrm{HQ}_{\mathrm{inh}}$ & $2.31 \mathrm{E}-06$ & $1.34 \mathrm{E}-05$ & $2.81 \mathrm{E}-04$ & $2.30 \mathrm{E}-07$ & $1.84 \mathrm{E}-07$ & $6.90 \mathrm{E}-07$ & $1.81 \mathrm{E}-05$ \\
\hline & $\mathrm{HQ}_{\text {demal }}$ & $3.34 \mathrm{E}-03$ & $2.52 \mathrm{E}-02$ & $5.28 \mathrm{E}-01$ & $4.32 \mathrm{E}-04$ & 3.09E-03 & $1.16 \mathrm{E}-02$ & $3.05 \mathrm{E}-01$ \\
\hline & $\mathrm{HI}$ & $3.74 \mathrm{E}-03$ & $2.54 \mathrm{E}-02$ & $5.29 \mathrm{E}-01$ & $5.87 \mathrm{E}-04$ & $4.02 \mathrm{E}-03$ & $1.16 \mathrm{E}-02$ & $3.05 \mathrm{E}-01$ \\
\hline
\end{tabular}




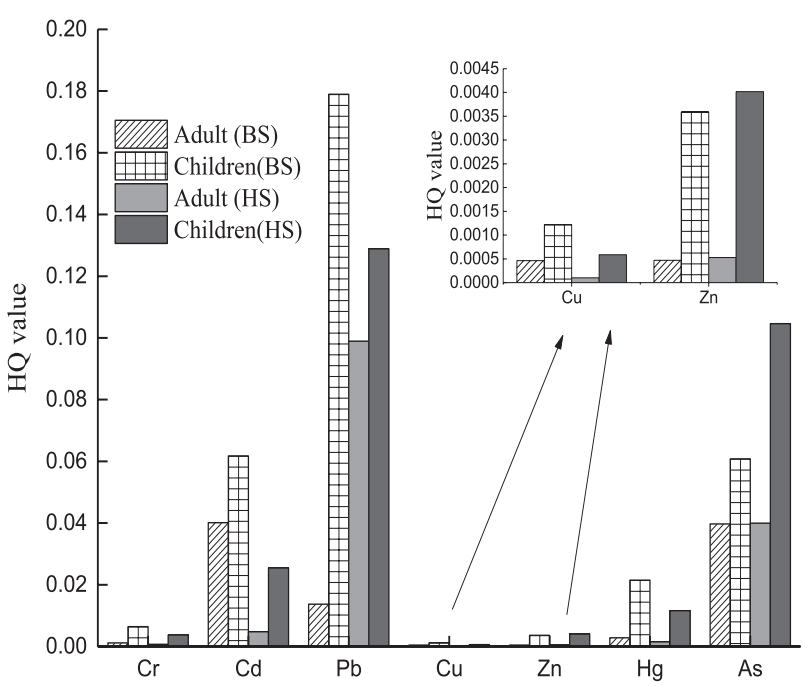

Fig. 3 The HQ values for adults and children at the different growth periods of rice.

(Fig. 3). Kaur et al. [40] reported the non-carcinogenic doses from the different exposure pathways and found that $\mathrm{CDI}_{\text {ing-nc }}>>\mathrm{CDI}_{\text {dermal }}>>\mathrm{CDI}_{\text {inh-nc }}$ for children, which may be due to the hand-to-mouth habits of children; the results were consistent with those in this study. The health risk assessment was effective for identifying toxic chemicals and various exposure pathways. However, the quantitative risk evaluation has several inherent uncertainties. Most importantly, the total concentration of heavy metals was used in this study, which will result in the overestimation of CDI and the resulting HI. Compared to the total amounts of heavy metals, the bioavailable or bio-accessible concentrations can provide a more reliable risk assessment for the environment and human health. In addition, the standards were proposed by the USEPA according to the environmental standards of the USA, and these exposure parameters for China may be not appropriate [41]. At present, exposure assessment guidelines for assessments of human health risks caused by heavy metals in soils have not been defined. Moreover, the proposed ABSs for heavy metals are relatively different between the USEPA and Canada, and their values have both been widely applied. This study primarily examined the three exposure pathways and the various heavy metals that lead to potential ecological and human health risks.

In both adults and children, the order of the carcinogenic doses of the different exposure pathways was $\mathrm{CDI}_{\text {ing }}>\mathrm{CDI}_{\text {inh }}>\mathrm{CDI}_{\text {dermal }}$ (Table 5), and the result was identical to that of Kaur et al. [40]. Generally, in the two stages, the order of $\mathrm{CF}$ values for adults and children was $\mathrm{Cd}>\mathrm{Cr}>\mathrm{As}>\mathrm{Pb}$ (Fig. 4). The carcinogenic risks posed by $\mathrm{Cr}, \mathrm{Cd}, \mathrm{As}$ and $\mathrm{Pb}$ in soils calculated for children were higher than those for adults. The CF values of the heavy metals mentioned in this study were lower than the acceptable threshold value of $1.0 \times 10^{-4}$ proposed by the USEPA, suggesting that they have no significant long-term health effects. Before

Table 5. Carcinogenic doses and risk associated with metal exposure in soil samples.

\begin{tabular}{|c|c|c|c|c|c|}
\hline \multirow{2}{*}{ Life stages } & \multirow{2}{*}{ Carcinogenic risks } & \multicolumn{4}{|c|}{ Heavy metals } \\
\hline & & $\mathrm{Cr}$ & $\mathrm{Cd}$ & $\mathrm{Pb}$ & As \\
\hline \multirow{4}{*}{$\begin{array}{l}\text { Adult (before sowing of } \\
\text { rice) }\end{array}$} & $\mathrm{CD}_{\text {ling }}$ & $5.46 \mathrm{E}-07$ & $7.46 \mathrm{E}-06$ & $3.26 \mathrm{E}-07$ & $9.96 \mathrm{E}-07$ \\
\hline & $\mathrm{CDI}_{\text {inh }}$ & $2.48 \mathrm{E}-09$ & $3.39 \mathrm{E}-11$ & $1.48 \mathrm{E}-09$ & $4.53 \mathrm{E}-10$ \\
\hline & $\mathrm{CDI}_{\text {demal }}$ & 8.72E-08 & 4.17E-07 & $7.81 \mathrm{E}-08$ & $1.19 \mathrm{E}-08$ \\
\hline & Total cancer risk & $6.36 \mathrm{E}-07$ & $7.88 \mathrm{E}-06$ & $4.06 \mathrm{E}-07$ & $1.01 \mathrm{E}-06$ \\
\hline \multirow{4}{*}{$\begin{array}{l}\text { Children (before sowing } \\
\text { of rice) }\end{array}$} & $\mathrm{CD}_{\text {ling }}$ & 8.34E-07 & $1.14 \mathrm{E}-06$ & 4.98E-07 & $1.52 \mathrm{E}-07$ \\
\hline & $\mathrm{CDI}_{\text {inh }}$ & 4.97E-11 & $6.78 \mathrm{E}-12$ & $2.97 \mathrm{E}-11$ & $9.06 \mathrm{E}-12$ \\
\hline & $\mathrm{CDI}_{\text {demal }}$ & $9.34 \mathrm{E}-08$ & $4.46 \mathrm{E}-08$ & 8.37E-09 & $1.28 \mathrm{E}-08$ \\
\hline & Total cancer risk & $9.27 \mathrm{E}-07$ & $1.18 \mathrm{E}-06$ & $5.06 \mathrm{E}-07$ & $1.65 \mathrm{E}-07$ \\
\hline \multirow{4}{*}{$\begin{array}{l}\text { Adult (Harvest stage of } \\
\text { rice) }\end{array}$} & $\mathrm{CD}_{\text {Iing }}$ & $3.18 \mathrm{E}-09$ & 3.07E-07 & $3.60 \mathrm{E}-08$ & 4.99E-09 \\
\hline & $\mathrm{CDI}_{\text {inh }}$ & $1.45 \mathrm{E}-11$ & $1.40 \mathrm{E}-12$ & $1.64 \mathrm{E}-11$ & $2.27 \mathrm{E}-12$ \\
\hline & $\mathrm{CDI}_{\text {demal }}$ & 5.08E-09 & 1.72E-09 & $8.63 \mathrm{E}-10$ & $5.97 \mathrm{E}-10$ \\
\hline & Total cancer risk & 8.27E-09 & 3.09E-07 & 3.69E-08 & $5.59 \mathrm{E}-09$ \\
\hline \multirow{4}{*}{$\begin{array}{c}\text { Children (Harvest stage of } \\
\text { rice) }\end{array}$} & $\mathrm{CD}_{\text {ling }}$ & 4.85E-09 & 4.69E-07 & $5.50 \mathrm{E}-08$ & 7.61E-09 \\
\hline & $\mathrm{CDI}_{\text {inh }}$ & $2.89 \mathrm{E}-12$ & $2.79 \mathrm{E}-13$ & $3.28 \mathrm{E}-12$ & $4.53 \mathrm{E}-13$ \\
\hline & $\mathrm{CDI}_{\text {demal }}$ & $9.34 \mathrm{E}-09$ & 4.46E-09 & $8.37 \mathrm{E}-10$ & $1.28 \mathrm{E}-11$ \\
\hline & Total cancer risk & $1.42 \mathrm{E}-08$ & 4.73E-07 & $5.58 \mathrm{E}-08$ & 7.62E-09 \\
\hline
\end{tabular}




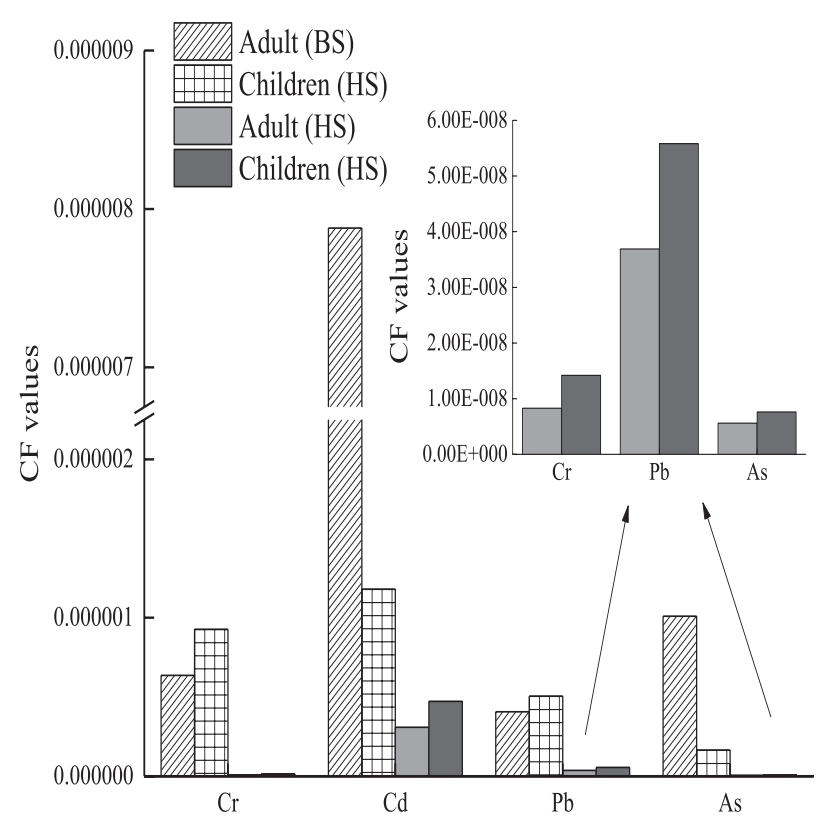

Fig. 4 The CF values for adults and children at the different growth periods of rice. rice sowing, the lifetime carcinogenic risk values for the local adults and children were $5.60 \times 10^{-5}$ and $8.15 \times 10^{-5}$, respectively. At the harvesting stage, the lifetime carcinogenic risk values for the local adults and children were $3.01 \times 10^{-5}$ and $4.48 \times 10^{-5}$, respectively. Overall, the CF values of all heavy metals were within the tolerable to acceptable risk range for local adults and children. No domestic, industrial or traffic pollution was found in the study area. Therefore, the local adults and children were not affected by the studied heavy metals based on the human health risk assessment. However, the $\mathrm{Cd}$ content of the soil was higher than the contents of the other heavy metals, which may be due to sewage irrigation and fertilizer application. In fact, the domestic waste produced by local residents enters ditches through runoff and man-made direct discharge, and the water in the ditches is used on farmland. Domestic waste may contain a small amount of heavy metals. In addition, the high $\mathrm{Cd}$ content in the soil was one of the reasons why the $\mathrm{CF}$ values of $\mathrm{Cd}$ for adults and children were higher than those of the other heavy metals.

Table 6. Bioavailability of simulated intestinal and gastric stages.

\begin{tabular}{|c|c|c|c|c|c|}
\hline \multirow{2}{*}{ Target } & \multicolumn{5}{|c|}{ Simulated gastric absorption stage (\%) } \\
\hline & $\mathrm{Pb}$ & $\mathrm{Zn}$ & $\mathrm{Cu}$ & $\mathrm{Cd}$ & As \\
\hline Maximum values & 31.45 & 74.12 & 21.87 & 2.15 & 0.88 \\
\hline Minimum values & 27.21 & 68.56 & 19.33 & 1.33 & 0.74 \\
\hline Average values & 29.33 & 71.34 & 20.6 & 1.74 & 0.81 \\
\hline \multirow{2}{*}{ Target } & \multicolumn{5}{|c|}{ Simulated intestinal absorption stage (\%) } \\
\hline & $\mathrm{Pb}$ & $\mathrm{Zn}$ & $\mathrm{Cu}$ & $\mathrm{Cd}$ & As \\
\hline Maximum values & 7.41 & 27.15 & 71.22 & 6.14 & 0.42 \\
\hline Minimum values & 5.95 & 23.83 & 67.36 & 4.38 & 0.17 \\
\hline Average values & 6.68 & 25.49 & 69.29 & 5.26 & 0.30 \\
\hline
\end{tabular}

Table 7 . The amount of heavy metals ingested by adults and children through the soil-human.

\begin{tabular}{|c|c|c|c|c|c|c|}
\hline \multirow{2}{*}{ Age } & \multirow{2}{*}{ Target } & \multicolumn{5}{|c|}{ Heavy metal intake $(\mu \mathrm{g} / \mathrm{d})$} \\
\hline & & $\mathrm{Pb}$ & $\mathrm{Zn}$ & $\mathrm{Cu}$ & $\mathrm{Cd}$ & As \\
\hline \multirow{4}{*}{ Adult } & Maximum values & 215 & 3652 & 650 & 39 & 213 \\
\hline & Minimun values & 258 & 2919 & 613 & 33 & 117 \\
\hline & Average values & 236 & 3285 & 631 & 36 & 165 \\
\hline & PTWI $^{*}$ & 429 & - & - & 60 & 129 \\
\hline \multirow{4}{*}{ Children } & Maximum values & 153 & 2600 & 463 & 28 & 152 \\
\hline & Minimun values & 184 & 2078 & 436 & 23 & 83 \\
\hline & Average values & 168 & 2339 & 449 & 26 & 64 \\
\hline & PTWI $^{*}$ & 107 & - & - & 30 & \\
\hline
\end{tabular}

Note: “*” refers to the conversion of weekly tolerance to daily tolerance. 
Table 8 . Bioavailability of heavy metals in different digestive stages of adults and children.

\begin{tabular}{|c|c|c|c|c|c|c|}
\hline \multirow{2}{*}{ Age } & \multirow{2}{*}{ Target } & \multicolumn{5}{|c|}{ Simulated gastric absorption stage (\%) } \\
\hline & & $\mathrm{Pb}$ & $\mathrm{Zn}$ & $\mathrm{Cu}$ & $\mathrm{Cd}$ & As \\
\hline \multirow{4}{*}{ Adult } & Maximum values & 153 & 51 & 134 & 11 & 2 \\
\hline & Minimun values & 184 & 51 & 126 & 10 & 1 \\
\hline & Average values & 168 & 57 & 130 & 11 & 1 \\
\hline & PTWI* & 429 & - & - & 60 & 129 \\
\hline \multirow{6}{*}{ Children } & Maximum values & 109 & 36 & 95 & 8 & 1 \\
\hline & Minimun values & 131 & 36 & 90 & 7 & 1 \\
\hline & Average values & 120 & 41 & 92 & 8 & 1 \\
\hline & PTWI* & 107 & - & - & 30 & 64 \\
\hline & \multirow{2}{*}{ Target } & \multicolumn{5}{|c|}{ Simulated intestinal absorption stage(\%) } \\
\hline & & $\mathrm{Pb}$ & $\mathrm{Zn}$ & $\mathrm{Cu}$ & $\mathrm{Cd}$ & As \\
\hline \multirow{4}{*}{ Adult } & Maximum values & 14 & 931 & 450 & 2 & 6 \\
\hline & Minimun values & 17 & 744 & 425 & 2 & 4 \\
\hline & Average values & 16 & 837 & 437 & 2 & 5 \\
\hline & PTWI* & 429 & - & - & 60 & 129 \\
\hline \multirow{4}{*}{ Children } & Maximum values & 10 & 663 & 321 & 1 & 5 \\
\hline & Minimun values & 12 & 530 & 302 & 1 & 2 \\
\hline & Average values & 11 & 596 & 311 & 1 & 4 \\
\hline & PTWI* & 107 & - & - & 30 & 64 \\
\hline
\end{tabular}

Note: "*” refers to the conversion of weekly tolerance to daily tolerance.

\section{In-vitro Simulation Test of $\mathrm{Cd}, \mathrm{Pb}, \mathrm{Cu}$ and $\mathrm{Zn}$}

Table 6 shows the bioavailability of $\mathrm{Pb}, \mathrm{Zn}, \mathrm{Cu}, \mathrm{Cd}$ and $\mathrm{As}$ in rice from the study area in the simulated gastric and intestinal stages. The bioavailability of $\mathrm{Zn}$ and $\mathrm{Cd}$ in rice in the study area was higher than that in the simulated intestinal stage, while the bioavailability of $\mathrm{Pb}, \mathrm{Cu}$ and $\mathrm{As}$ was lower than that in the simulated intestinal stage [12]. The difference in the bioavailability of $\mathrm{Pb}, \mathrm{Zn}, \mathrm{Cd}$ and $\mathrm{Cu}$ may be caused by the different acid conditions in the stomach. The bioavailability of As in the simulated stomach stage and the simulated intestinal stage in the study area was low, which implied that the bioavailability of As in the simulated experiment was not affected by the acidic conditions. Since the national food hygiene standard (GB2762-2012) does not include $\mathrm{Zn}$ and $\mathrm{Cu}$ as pollutant indicators, the per tolerable weekly intake (PTWI) of $\mathrm{Zn}$ and $\mathrm{Cu}$ in rice was not considered in this study. The standard showed that the PTWI values of $\mathrm{Cd}$ and As were $7.00 \mu \mathrm{g} / \mathrm{kg}$ and $15 \mu \mathrm{g} / \mathrm{kg}$, respectively [12]. The limit values for $\mathrm{Pb}$ in adults and children are $50.00 \mu \mathrm{g} / \mathrm{kg}$ and $25.00 \mu \mathrm{g} / \mathrm{kg}$, respectively. For adults weighing $60 \mathrm{~kg}$ and children weighing $30 \mathrm{~kg}$, the daily intake of Cd should not exceed 60.00 and $30.00 \mu \mathrm{g} / \mathrm{d}$, respectively, the daily intake of $\mathrm{Pb}$ should not exceed 428.57 and
$107.14 \mu \mathrm{g} / \mathrm{d}$, respectively, and the daily intake of As should not exceed 128.57 and $64.29 \mu \mathrm{g} / \mathrm{d}$ [12]. Table 7 shows that the average daily intake of $\mathrm{Pb}, \mathrm{Zn}$, $\mathrm{Cu}, \mathrm{Cd}$ and As content ranges from 215-258, 2919-3652, 613-650, 33-36, and 117-213 $\mu \mathrm{g} / \mathrm{d}$, respectively. The average daily intake of $\mathrm{Pb}, \mathrm{Zn}, \mathrm{Cu}, \mathrm{Cd}$ and $\mathrm{As}$ in the study area was 153-184, 2078-2600, 436-463, 23-28 and $83-152 \mu \mathrm{g} / \mathrm{d}$, respectively. In this study, only children were at risk of ingesting more than the weekly limit for $\mathrm{Pb}$ by eating rice grown in the study area.

Table 8 shows the total amount of heavy metals ingested by adults and children by eating the local rice. The bioavailable amounts of the heavy metals did not exceed the PTWI values, indicating that there was no health risk from eating the local rice. However, the bioavailability of $\mathrm{Pb}, \mathrm{Zn}, \mathrm{Cu}, \mathrm{Cd}$ and $\mathrm{As}$ in rice in this study area was higher in the simulated gastric digestion stage than in the simulated small intestine stage, which may be related to the acidic environment in the stomach. In the simulated small intestine stage, the intestinal fluid was alkaline, which led to a decrease in the bioavailability of heavy metals in rice. Since the absorption function of the human digestive tract to food was mainly reflected in the small intestine stage, the availability of heavy metals in rice in the simulated small intestine stage plays a more important role in the 
whole in-vitro simulation experiment. In addition to the bioavailability of heavy metals in the human body, there are also other factors that affect human health risk assessments, such as individual differences and dietary habits. The purpose of this study was to evaluate the health risks of eating rice from the perspective of heavy metal intake and bioavailability.

\section{Conclusions}

Before rice sowing and at the rice harvesting stage, the $\mathrm{pH}$ values of the soils ranged from 7.93 to 8.14 and 7.91 to 8.04 , respectively. In both stages, the order of $\mathrm{I}_{\text {geo }}$ values (besides those of $\mathrm{Pb}$ and $\mathrm{Zn}$ ) was $\mathrm{Cd}>\mathrm{As}>\mathrm{Hg}>\mathrm{Cu}>\mathrm{Cr}$. Moreover, the heavy metals with lower $\mathrm{I}_{\text {geo }}$ values exhibited lower risk at the two stages in the study areas. The farmland in the study area was not polluted by heavy metals according to the evaluation of their total contents and chemical speciation. The order of $\mathrm{BCF}$ values was $\mathrm{Cd}>\mathrm{Cu}>\mathrm{Zn}>\mathrm{Pb}>\mathrm{As}>\mathrm{Cr}>\mathrm{Hg}$. For all heavy metals, the non-carcinogenic doses of the different exposure pathways indicated that $\mathrm{CDI}_{\text {ing-nc }}>\mathrm{CDI}_{\text {dermal }}>\mathrm{CDI}_{\text {inh-nc }}$ for children and adults. The HI values for adults and children for heavy metals before rice sowing were 0.0984 and 0.634 , respectively, indicating that these metals have little influence on the human body. The HI values for adults and children for the heavy metals at the rice harvesting stage were 0.146 and 0.879 , respectively. Before rice sowing, the lifetime carcinogenic risk values for the local adults and children were $5.60 \times 10^{-5}$ and $8.15 \times 10^{-5}$, respectively. At the rice harvesting stage, the lifetime carcinogenic risk values for local adults and children were $3.01 \times 10^{-5}$ and $4.48 \times 10^{-5}$, respectively. At the two stages, the order of $\mathrm{CF}$ values for adults and children was $\mathrm{Cd}>\mathrm{Cr}>\mathrm{As}>\mathrm{Pb}$. The total amounts and bioavailable amounts of heavy metals ingested by adults and children through eating the local rice did not exceed the tolerable weekly intake values, indicating that there is no health risk from eating the local rice. However, draining and drying the field in time can improve the Eh value of the paddy soil.

\section{Author Contributions}

C. H. designed and wrote the research; W. X., C. C. and T. C. performed the experiments and data analysis.

\section{Acknowledgements}

This work was financially supported by Environmental Engineering Subject with OpenEnd Fund in Key Laboratory in Jiangsu Province for Scientific Research(KF2015007), Surface Project of Scientific Research of Institutions of Higher Learning in Jiangsu Province (17KJB610002), Environmental
Engineering Subject with Open-End Fund in Key Laboratory in Jiangsu Province for Scientific Research (KF2015005).

\section{Conflict of Interest}

The authors declare no conflict of interest.

\section{References}

1. YANG T.H., DIAO X.P., CHENG H.M., WANG H.H., ZHOU H.L., ZHAO H.G., CHEN C.M. Comparative study of polycyclic aromatic hydrocarbons (PAHs) and heavy metals (HMs) in corals, sediments and seawater from coral reefs of Hainan, China. Environ. Pollut. 264, 114719, 2020.

2. WU X.L., HU J.W., QI J.M., HOU Y., WEI X.H. Graphenesupported ordered mesoporous composites used for environmental remediation: A review. Sep. Purif. Technol. 239, 116611, 2020.

3. DING Y., ZONG L.G., XU X.Y., LIU G.R. Effect of cadmium on the growth and quality of rice (Oryza saliva L.) in different growth period. Ecology and Environment, 18 (1), 183, 2009 [In Chinese].

4. ZHANG M., SHAN S.D., CHEN Y.G., WANG F., YANG D.Y., REN J.K., LU H.Y., PING L.F., CHAI Y.J. Biochar reduces cadmium accumulation in rice grains in a tungsten mining area-field experiment: effects of biochar type and dosage, rice variety, and pollution level. Environ. Geochem. Hlth. 41, 43, 2019.

5. VOLPE M.G., CARA F.L., VOLPE F., MATTINO A.D., SERINO V. PETITTO F., ZAVALLONI C., LIMONE F., PELLECCHIA R., PRISCO P.P.D., STASIO M.D. Heavy metal uptake in the enological food chain. Food Chem. 117 (3), 553, 2009.

6. LI D.Q., WANG L.L., WANG Y.H., LI H.S., CHEN G.K. Soil properties and cultivars determine heavy metal accumulation in rice grain and cultivars respond differently to Cd stress. Environ. Sci. Pollut. Res. Int. 26 (14), 14638, 2019.

7. LEI M., TIE B.Q., SONG Z.G., LIAO B.H., LEPO J.E., HUANG Y.Z. Heavy metal pollution and potential health risk assessment of white rice around mine areas in Hunan Province, China. Food Sec. 7, 45, 2015.

8. ROGAN N., SERAFIMOVSKI T., DOLENEC M., TASEV G., DLLENEC T. Heavy metal contamination of paddy soils and rice (Oryza sativa L.) from Kočani Field (Macedonia). Environ. Geochem Health 31, 439, 2009.

9. ACHARYA P., JAYAPRAKASHA G.K., CROSBY K.M., JIFON J.L., PATIL B.S. Nanoparticle-mediated seed priming improves germination, growth, yield, and quality of watermelons (Citrullus lanatus) at multi-locations in Texas. SCI. Rep-UK. 10 (1), 5037, 2020.

10. DENG B.L., YANG K.L., ZHANG Y.F., LI Z.T. Can heavy metal pollution defend seed germination against heat stress? Effect of heavy metals $\left(\mathrm{Cu}^{2+}, \mathrm{Cd}^{2+}\right.$ and $\left.\mathrm{Hg}^{2+}\right)$ on maize seed germination under high temperature. Environ. Pollut., 216, 46, 2016.

11. ZHANG Z.M., WU X.L., WU Q.S. HUANG X.F. ZHANG J.C. FANG H. Speciation and accumulation pattern of heavy metals from soil to rice at different growth stages in farmland of southwestern China. Environ. Sci. Pollut. R. 27, 35675, 2020. 
12. LAN D.Z., LEI M., ZHOU S., LIAO B.H., CUI Y.S. YIN N.Y., SHEN Y. Health risk assessment of heavy metals in rice grains from a mining-impacted area in south Hunan by in vitro simulation method. Journal of Agro-Environment Science 33 (10), 1897, 2014 [In Chinese].

13. CHEN C., GUO X.Y., WANG M., JIA Y.X., CHEN S.B. Human health risk assessment of $\mathrm{Cd}$ in vegetables and the remediation effect of Cd-polluted soil evaluated using an in-vitro simulation test. Journal of Agricultural Resources and Environment 37 (1), 144, 2020.

14. MULLER G. Index of geoaccumulation in sediments of the Rhine River. Geo. Journal 2, 109, 1969.

15. LIU M.X., HAN Z.Q., YANG Y.Y. Accumulation, temporal variation, source apportionment and risk assessment of heavy metals in agricultural soils from the middle reaches of Fenhe River basin, North China. RSC Adv. 9 (38), 21893, 2019.

16. JHENELLE A.W., ANTOINE J. Evaluation of the elemental pollution status of Jamaican surface sediments using enrichment factor, geoaccumulation index, ecological risk and potential ecological risk index. Mar. Pollut. Bull. 157, 111288, 2020.

17. YU H.Y., LI T.J., LIU Y., MA L.M. Spatial distribution of polycyclic aromatic hydrocarbon contamination in urban soil of China. Chemosphere, 230, 498, 2019.

18. LI Z.Y., MA Z.W., KUIJP T.J.V.D., YUAN Z.W., LWI H. A review of soil heavy metal pollution from mines in China: Pollution and health risk assessment. Sci. Total Environ. 468-469, 843, 2014.

19. WANG D., SU C., ZHANG W., HAO X.Z., CANG L., WANG Y.J., ZHOU D.M. Laboratory assessment of the mobility of water-dispersed engineered nanoparticles in a red soil (Ultisol). J. Hydrol. 519, 1677, 2014.

20. LI S., LI H., LIANG X.Q., CHEN Y.X., CAO Z.H., XU Z.H. Rural wastewater irrigation and nitrogen removal by the paddy wetland system in the Tai Lake region of China. J. Soil. Sediment. 9 (5), 443, 2009.

21. HAN W., LUO L., ZHANG S.Z. Adsorption of tetrabromobisphenol A on soils: Contribution of soil components and influence of soil properties. Colloid. Surface. A. 428 (13), 60, 2013.

22. CHAI M.W., LI R.L., TAM N.F.Y., ZAN Q.J. Effects of mangrove plant species on accumulation of heavy metals in sediment in a heavily polluted mangrove swamp in Pearl River Estuary, China. Environ. Geochem. Hlth. 41 (1), 175, 2019.

23. LVAN T., NATALIA K., NIKOLAY K. Health risk assessment based on the contents of potentially toxic elements in urban soils of Darkhan, Mongolia. J. Environ. Manage. 242 (15), 279, 2019.

24. AZMAT Z., MUHAMMAD Z.H., RIFFAT N.M., ZULKIFL A. Enrichment and geo-accumulation of heavy metals and risk assessment of sediments of the Kurang Nallah-Feeding tributary of the Rawal Lake Reservoir, Pakistan. Sci. Total Environ. 470-471, 925, 2014.

25. TAO X.Q., SHEN D.S., SHENTU J.L., LONG Y.Y., SHEN C.C. Bioaccessibility and health risk of heavy metals in ash from the incineration of different e-waste residues. Environ. Sci. Pollut. R. 22 (5), 3558. 2015.

26. XUE Z.J., LIU S.Q., LIU Y.L., YAN Y.L. Health risk assessment of heavy metals for edible parts of vegetables grown in sewage-irrigated soils in suburbs of Baoding
City, China. Environ. Monit. Assess. 184 (6), 3503, 2012.

27. ZHONG W.J., ZHANG Y.F., WU Z.H., YANG R.Y., CHEN X.Y., YANG J., ZHU L.Y. Health risk assessment of heavy metals in freshwater fish in the central and eastern North China. Ecotox. Environ. Safe. 157, 343, 2018.

28. DIAMI S. M., KUSIN F. M., MADZIN Z. Potential ecological and human health risks of heavy metals in surface soils associated with iron ore mining in Pahang, Malaysia. Environ. Sci. Pollut. R. 23 (20), 21086, 2016.

29. RUBY M.V., DAVIS A. SCHOOF R., EBERLE S., SELLSTONE C.M. Estimation of lead and arsenic bioavailability using a physiologically based extraction test. Environ. Sci. Technol. 30 (2), 422, 1996.

30. ROBIN R.R., NICHOLAS T.B., STAN W.C., LANNY W.P. An in vitro gastrointestional method to estimate bioavailable arsenic in contaminated soils and solid media. Environ. Sci. Technol. 33 (4), 642, 1999.

31. YANG P., LIU, S.B., XIE, Y.H. ZHOU, Y.J. GUAN, D., JI, X.H. Effect of thiol activated silicon on contents of cadmium in soil and rice under different $\mathrm{pH}$ conditions. Journal of Henan Agricultural Sciences, 47, 46, 2018 [In Chinese].

32. YUE X.H., CAO J., GENG J., LI J., ZHANG Z.J., ZHANG L.J. Effects of different types of salt stress on growth, ion balance and rhizosphere $\mathrm{pH}$ changes in beer barley seedlings. Acta Ecologica Sinica, 38 (20), 228, 2018 [In Chinese].

33. PANZARINO O., HYRSL P., DOBES P., VOJETK L., VERNILE P., BARI G., TERZANO R., SPAGNUOLO M., LILLO E.D. Rank-based biomarker index to assess cadmium ecotoxicity on the earthworm Eisenia andrei. Chemosphere, 145, 480, 2016.

34. LI D., GUI C.X., JI G.Z., HU S.Y., YUAN, Z.Z. An interpretation to $\mathrm{Cr}(\mathrm{VI})$ leaching concentration rebound phenomenon with time in ferrous-reduced $\mathrm{Cr}(\mathrm{VI})$-bearing solid matrices. J. Hazard. Mater. 378, 1207341, 2019.

35. YU S.W., LIU, Y.B. Current situation and prospects of researches on heavy metals pollution in soil - rice system. Acta Agriculturae Jiangxi 16, 41, 2004 [In Chinese].

36. DAI Y., YANG C.F., ZHEN Y.M. A review on environmental behavior and toxicity assessment of chromium in soil-plant system. Environmental Science $\mathbf{3 3}$ (11), 314, 2009 [In Chinese].

37. REDDY C.N., PATRICK W.H. Effect of redox potential and $\mathrm{pH}$ on the uptake of cadmium and lead by rice Plants. J. Environ. Qual. 6 (3), 259, 1977.

38. HU X., ZHANG Y., LUO J., XIE M., WANG T. LIAN H. Accumulation and quantitative estimates of airborne lead for a wild plant (Aster subulatus). Chemosphere 82 (10), 1351, 2011.

39. WOJAS S., RUSZCZYNSKA A., BULSKA E. $\mathrm{Ca}^{2+}$ dependent plant response to $\mathrm{Pb}^{2+}$ is regulated by LCT1. Environ. Pollut. 147, 584, 2007.

40. KAUR R., BHATTI S., SINGH S., SINGH J. Phytorenediation of heavy metals using cotton plant: a field analysis. Bull. Environ. Contam. Toxicol. 101 (5), 637, 2018.

41. JIA Z., LI S., LI W. Assessment of soil heavy metals for ecoenvironment and human health in a rapidly urbanization area of the upper Yangtze Basin. Sci. Rep-UK 8, 3256, 2018. 